\title{
Kairotic Time, Recognition, and Freedom in James Baldwin's Go Tell It on the Mountain
}

\author{
Robert Z. Birdwell Tulane University
}

\begin{abstract}
Go Tell It on the Mountain sheds light on James Baldwin's response to his Pentecostal religious inheritance. Baldwin writes protagonist John Grimes's experience of "salvation" as an act of his own break with his past and the inauguration of a new vocation as authorial witness of his times. This break is premised on the experience of kairos, a form of time that was derived from Baldwin's experience of Pentecostalism. Through John Grimes's experience, Baldwin represents a break with the past that begins with the kairotic moment and progresses through the beginnings of self-love and the possibility of freedom enabled by this love. This essay contributes a new perspective on discussions of Baldwin's representation of time and his relationship to Christianity.
\end{abstract}

Keywords: Go Tell It on the Mountain, kairos, recognition, freedom

James Baldwin said that Go Tell It on the Mountain "is the book I had to write if I was ever going to write anything else ... I had to deal with what hurt most. I had

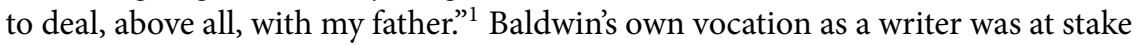
in the writing of this autobiographical first novel, one Sabbath in the life of John Grimes, a 14-year-old who is apparently destined for the ministry in Pentecostal Christianity but who has so far resisted undergoing the moment of "salvation." Go Tell It on the Mountain tells the story of John's experience of salvation, yet the result of this experience is ambiguous: it is not clear whether the novel concludes with a John Grimes who is destined to become a preacher, or a John Grimes who is destined to do otherwise. It is precisely this ambiguity of destiny, the possibility of doing otherwise, that suggests the meaning of John's experience is not destiny but freedom: the freedom to realize himself in his vocation, whatever that vocation 
turns out to be. There is a striking parallel between John's freedom within Go Tell It on the Mountain and Baldwin's own freedom to pursue his vocation as a consequence of writing the novel. David Leeming, Baldwin's secretary and biographer, describes the dilemma that Baldwin casts in figurative terms during the protagonist's "threshing floor" scene, the climactic moment of salvation. That scene, writes Leeming, is "a metaphor for the real story-the inner story-of James Baldwin." The author's inner story, then, is to be free of his Pentecostal religious heritage and yet still be witness to an African-American community in part constituted by that heritage.

Kairos is the form of time that enables John's and Baldwin's attempts to break with the past. Through John's redemptive experience, Baldwin presents an experience of kairos - the time of opportunity for redemption - that he originally derived from his experience of Pentecostal Christianity and its emphasis on the moment of salvation. Baldwin's use of this form of time, however, is a condition of possibility for a break with the expectations that Christianity placed on him and his alternative self-affirmation of himself as an authorial "witness." In Go Tell It on the Mountain Baldwin both witnessed history and, in a kairotic moment, "broke" with history. By history here I mean the tragic sense of chronos: an inevitable, oppressive march of events comprised, in part, by one's paternal and social past. History, as Fredric Jameson puts it in his synthesis of psychoanalysis and historicism, is "the experience of Necessity... History is what hurts, it is what refuses desire and sets inexorable limits to individual as well as collective praxis." ${ }^{3}$ If history as necessity is the point of departure for this essay, however, it is not the endpoint because I read Baldwin's novel as an exception to this necessity; the novel is a testament to the utopian time of kairos. By the word utopian I mean to point to a realm of freedom within the realm of necessity constituted by chronos. Utopia is the term for a break with a realm of necessity and passage to a realm of freedom.

It will perhaps be objected that the protagonist of Go Tell It on the Mountain is the 14-year-old John Grimes, not Baldwin himself, so that conclusions about the author's experience cannot be inferred from the character's experience. This essay does not make such an inference, but it does attempt to take seriously Baldwin's own twofold claim about the text: that its writing was a process of working through trauma inherited from his father and that it was the book that had to be written before anything else could be written. This claim reveals a striking parallel between James Baldwin and John Grimes, for both author and character wrestle in this book with questions of the paternal past and vocational future. This essay will offer a perspective on John's process of working through the past-to free himself to live in the future-that sheds light on Baldwin's own process of movement from past to present through a moment of kairos. The kairos that is a precondition of freedom is a utopian experience of time. To be more exact, kairos is not a favorable place but a favorable time-and hence it is available even in the midst of the realities of an oppressive family and society.

Mikko Tuhkanen has analyzed Baldwin's sense of time by utilizing the notion of the "untimely now." On the one hand, Tuhkanen argues that Baldwin's sense 
of time focuses on the now, rejecting gradualism and focusing urgently on the political demands of the present. On the other hand, Tuhkanen notes that Baldwin witnesses not merely to the present but also to the "disavowed past": "Baldwin's ethics of witnessing seeks a detente-a thawing of diasporic memory-where the disavowed past would alleviate the defensive focus on the present... The witness holds the past open as a realm of potential from which newness can emerge." Baldwin remains focused on the now, yet the now contains the potential of the past and the promise of the future. Tuhkanen concludes that "other times still infect the present moment's singular exigency." I agree with Tuhkanen that Baldwin's concern is with the untimely now. In Go Tell It on the Mountain, part of the disavowed past is the liberatory potential of religious language through the enabling of selflove. ${ }^{7}$ The form of time in Go Tell It on the Mountain, I find, is kairotic time, which begins with but is infinitely more expansive than the punctual now. The now that John Grimes witnesses gathers moments, past and present, into the urgent time of opportunity called kairos: all of John's' fourteen years-and all of his indefinitely long future as witness to the community-focus on the moment of redemption upon the threshing floor.

Kairos is defined as the time that is favorable for action; in the New Testament, kairos is the right time for redemptive action. For example, after Jesus successfully endures his temptation by the devil in the desert, he returns to society to begin "preaching the gospel of the kingdom of God, and saying 'The time [kairos] is fulfilled, and the kingdom of God is at hand: repent ye, and believe in the gospel."' In opposition to kairos, chronos is a sequential, chronological, forward-moving form of time-the form that, for the ancient Greeks, was a kind of realm of necessity or fate. Chronos in this sense is counterposed to the kairotic opportunity of deliverance from the toils of necessity. For the ancient Greeks, chronos is the more comprehensive concept. According to R. C. Trench, this sense of "chronos encompasses ... all possible kairoi." Such an all-encompassing sense of chronos was indeed fatalistic. As H.-C. Hahn puts it, ancient "Greek man experienced time as a power which inescapably determined his life." 10 The trend toward the prominence of kairos in the Tanakh intensifies in the Christian New Testament, for the "decisively new and constitutive factor for any Christian conception of time is the conviction that, with the coming of Jesus, a unique moment of kairos has opened up, one by which all other time is qualified." ${ }^{11}$ If for the Greeks chronos was the comprehensive concept of time, for the Christians of the New Testament kairos was the dominant, enveloping concept. Within the kairotic time of the New Testament, the ostensibly powerless-"men fishing by the shores of Galilee, and black men weeping on their knees tonight, and [John Grimes], a witness" ${ }^{\prime 2}$ - would recognize themselves, thus attaining agency, the ability to transform the course of history.

Baldwin's representation of kairos in his first novel, however, suggests that his imagined break with his childhood religion was not complete: in breaking with that religion, he simultaneously reimagined it. Many critics have commented on the author's vexed connection with Christianity. The question of Baldwin's relationship to Christianity is troublesome in part because Jesus himself may appear, to borrow a phrase from Baldwin's essay "Many Thousands Gone," to be an "alabaster Christ." ${ }^{3}$ 
I take this remark to suggest a certain conception of Jesus as both the private property and ideological justification of a white, segregated American Christendom. An alabaster Christ is a dubious source of redemption for a black church. Indeed, for John Grimes, his religious tradition seems inextricable from the old slaveholding apologist's appeal to the curse of Ham, "that son of Noah's" who, as Baldwin writes, "had been cursed, down to the present groaning generation" (p. 200). This appeal to Noah's curse is a transparent, though tenacious, ideology, and the alabaster Christ is a whitewashed, Western Christ. But Baldwin demurs, telling Nikki Giovanni that in Pentecostalism, and in what he considers to be the black church in general, Jesus "had to be fairly dark." ${ }^{14}$ The alabaster Christ is not the God of color to whom Go Tell It on the Mountain bears witness.

It has been argued that Baldwin is inconsistent in his simultaneous use of Christian vocabulary and criticism of that same vocabulary. Barbara K. Olson concludes that "Baldwin's intended denunciation [of his childhood faith] was undermined by the black church idiom he chose to use."15 Is there a more charitable way of capturing Baldwin's ambivalence about a black church idiom? In the face of such a debate about Baldwin's relationship to his strand of Christianity, a "dialectical" solution such as the one offered by Michael F. Lynch seems promising. Lynch detects a "personal quest for the hidden God" that persists despite Baldwin's rejection of his father Gabriel's repressive and judgmental version of the faith. ${ }^{16}$ Lynch's reading sees Baldwin's theology as a paradoxical but not contradictory "humanist theology," a theology without God. Lynch calls this theology "fundamentally dialectical," "striving to reconcile the conflict by exploring the truth of both positions." ${ }^{17}$ In a remark that resonates with Lynch's humanist theology, George Shulman calls Baldwin a "nontheistic prophetic voice": "nontheistic because he does not announce God's words or point of view as a messenger, but prophetic because, on the avowed basis of experience, social position, and artistic vision, he announces what is disavowed and unsayable and testifies to what he sees and stands against it."18

I agree with Lynch's and Shulman's dialectical contentions because, as I will show in the reading of the climactic moment of the novel, God himself seems to merge in a unity with the queer young black man John Grimes himself. In Baldwin's conversation with Margaret Mead, A Rap on Race, he confesses that "in my case, in order to become a moral human being... I have to hang out with publicans and sinners, whores and junkies, and stay out of the temple where they told us nothing but lies anyway." ${ }^{19}$ Mead answers, "This is, of course, what Jesus did too," and Baldwin replies that "it is only in that sense that I can be called a Christian.," Baldwin's sense of being a Christian involves recognizing Jesus's call for the urgency of solidarity with social outcasts. In this sense, Baldwin establishes both distance from and continuity with his particular strand of black Christianity.

In the passage from kairos to freedom there is an intermediate step, the process of recognition. Baldwin's kairotic time, derived from his experience of Christianity, was a condition of possibility for his own act of self-recognition in writing Go Tell It on the Mountain. The elements of this inheritance were a kairotic experience of time and the narrative emplotment of a Christian Bible-i.e., the Old and New Testaments taken as a continuity-that this time encompasses. Baldwin puts a 
conservative narrative structure and the view of time that it presupposes to a revolutionary use: an act of self-recognition or self-affirmation of a young queer black man. By recognition, however, I mean an act of love, not a discovery of identity. ${ }^{21}$ In this conception of recognition I follow Axel Honneth, who conceives of recognition as progressive stages in the growth of the subject in society. This process of growth begins with love, continues with equality, and culminates in solidarity. Love is the fundamental act of recognition, the sine qua non of future formation of the subject, since without love one lacks the confidence to make claims to equality and solidarity within society. ${ }^{22}$ I would contend that recognition is a source of selflove that is made possible by the kairotic moment. Recognition, then, enables one's own, autonomous ends-not just the ends of equality and solidarity but of one's own vocation.

In his moment of kairos John Grimes moves from ambivalent self-loathing to self-love. This self-love is the precondition for John's freedom: his ability to make a kairotic break with the judgmental strictures of the past. John's act of selfrecognition or self-affirmation was the act that Baldwin, too, had to make if he was to become a witness to his own life and to his historical moment. If Go Tell It on the Mountain was the novel Baldwin had to write before anything else, this is because this novel was the means by which he could dialectically overcome the religious and literary tradition by negating its conservatism, preserving its redemptive potential, and elevating it to the level of a personal act of recognition-all in order to become the witness that he was. As Greg Miller remarks, "it would be fair to say that [Baldwin] always remained a preacher." ${ }^{23}$ This reading of Go Tell It on the Mountain proposes a new perspective on the relationship between Baldwin and his childhood form of Christianity, a relationship of critical appropriation that is dialectical rather than contradictory, thus relating Baldwin as both critic and acolyte of a "Western" tradition of epic narrative.

The kairos of Go Tell It on the Mountain derives from the King James Bible of Baldwin's childhood. As many have noted, the novel is richly biblical in its language. Shirley S. Allen provides a detailed account of allusions to the Bible in Go Tell It on the Mountain, emphasizing "the central importance of the religious symbolism," but it is equally important to highlight the plot structure that the two books share. ${ }^{24}$ The structure of the Christian Bible as Old and New Testament begins with Genesis, moves through the salvation history of the Jewish people and through the expansion of that history to the gentiles. It culminates in the Book of Revelation, in which humanity is judged, Christ returns, and a new heaven and a new earth are established through divine agency. ${ }^{25}$ Go Tell It on the Mountain follows this three-part sequence of creation, history, and revelation. Accordingly, as Csaba Csapó notes, the opening part is "The Seventh Day," the Sabbath following the creation of the world. ${ }^{26}$ This particular Saturday in the spring of 1935 in Harlem is John Grimes's fourteenth birthday. Part Two, "The Prayers of the Saints," accounts for the time John spends in church, during which histories of his family are interspersed, from the period of slavery through the Great Migration to the present Great Depression. The third and final part, "The Threshing Floor," tells the story of John's ecstatic 
vision of God, which recalls John of Patmos's book of Revelation, the conclusion of the New Testament. ${ }^{27}$

Baldwin's kairotic time breaks with the paternal, heteronormative expectations of John's own salvation. The sin from which John must be redeemed is most immediately associated in his body with sexual desire for a young man, his mentor Elisha. The kairos of John's redemption is a reversal of the community's expectation. John is liberated not to be a pious lover of Jesus and the "opposite sex" but liberated to the possibility of loving and being as he will-and to attest to these new possibilities for others. ${ }^{28}$ This theological reading resonates with Csapós analysis of Go Tell It on the Mountain. Csapó relates race and sexuality in his reading of John's character, arguing that "Baldwin's position is especially interesting because he synthesizes race and gay consciousness during some of the most politically volatile decades of the twentieth century."29

Kairos, recognition, and freedom are intimately related in Go Tell It on the Mountain. At the close of the novel John does not belong to any community, but he does belong to himself in the sense that he recognizes or affirms himself and assumes agency or the capacity for free action on the basis of this recognition. If Gabriel's scriptural slogan is to "Set thine house in order," John's salvation is a reordering of the house (pp. 26, 61). In this aleatory moment of kairos John's question becomes urgent for the first time: "What shall I do? What shall I do?" (p. 24).

His community anticipates a successful life of spiritual leadership for John: "it was said that he had a Great Future. He might become a Great Leader of His People" (p. 12). Casting doubt on these predictions is John's own question "whether his face was ugly or not," a dilemma that seems answered by the indifferent or contemptuous faces of white passersby in Manhattan, "whose eyes held no love for him" (pp. 21, 27). ${ }^{30}$ Go Tell It on the Mountain opens with an apparent statement of fate:

Everyone had always said that John would be a preacher when he grew up, just like his father. It had been said so often that John, without ever thinking about it, had come to believe it himself. Not until the morning of his fourteenth birthday did he really begin to think about it, and by then it was already too late. (p. 3)

The referent of "everyone" here seems to stretch beyond John's family to the whole congregation of the Temple of the Fire Baptized. However, in the backward-looking "Prayers of the Saints," the family and community in Go Tell It on the Mountain come to represent an even larger portrait of African-American history, from slavery through the Great Migration to the Great Depression. Baldwin thus grants a strong voice to determinism or chronos in the novel. John's aunt Florence, a solid presence of sanity and equanimity in the family, remarks to her brother, "You can't change nothing, Gabriel. You ought to know that by now" (p. 44).

If the referent of "everyone" is indeterminate, the meaning of "too late" is also ambiguous. Too late for what? Too late not to become a preacher, or too late to become a preacher? Or perhaps too late because the future is already totally determined? The matter of whether John is initially fated or free seems only 
muddier when Baldwin tells us early on that John has "made his decision. He would not be like his father, or his father's fathers. He would have another life" (p. 12). This report of John's decision may be ironic, Baldwin's hint that a 14-year-old's selfunderstanding is hardly decisive and his vision hardly clear. Indeed, Baldwin goes on to poke fun at the community's own view, focalizing its perspective with wry capital letters in the Great Future of the Great Leader. This is a prediction that, with a little ambivalence, John fantasizes: "He was a poet, or a college president, or a movie star; he drank expensive whisky, and he smoked Lucky Strike cigarettes in the green package" (p. 12). Here Baldwin appears to treat John's alternative future, his decision, as a mere boyish fantasy. Both John and the community have definite ideas about his future, and both ideas are presented as a little absurd. Again, is it too late for John to avoid becoming a preacher, or too late to become a preacher? Baldwin poses the question of John's fate or freedom not with a definite answer but with a tangle of contending possibilities. The most realistic view of the future, perhaps, is suggested by Roy, who answers the scolding of his mother with the question, "You think that's all that's in the world is jails and churches?" (p. 18). Though Roy would like a third alternative to jails and churches, his rhetorical question nonetheless highlights the constraints on agency that he and John face as young African-American men in 1930s Harlem. The community imagines for John no vision of greatness other than the church, and his mother imagines for Roy no fate other than the jail. However, John's freedom is the agency to refuse to follow in the ministry of his adopted father and rather to continue the witness of his tragic biological father, Richard, who refers to Jesus as a "puking bastard" (p. 164). Despite this blasphemy, his suicide sets him apart and attests to the integrity of one who will not tolerate the shame of fate, whether that fate be of a racist justice system or a judgmental church. In a sense, Richard's attitude determines John's, but it thereby cancels out the fate, the consequence of chronos that is threatened by Gabriel.

The transformation of banal time via Baldwin's radical inversion of biblical time begins in part one, "The Seventh Day." This is no day of rest. First, John leaves his house for a walk through the city. Then he goes to the church to clean and prepare for the service. In one sense, the trip to the city is a fantasy typified by the picture of white sensuality and wealth through the sights in the movie theater and Central Park; nonetheless this fantasy appears more real than the lure of religion: "And then what of his soul, which would one day come to die and stand naked before the judgment bar? What would his conquest of the city profit him on that day? To hurl away, for a moment of ease, the glories of eternity?" (p. 28). The inevitable sense of time as John experiences it is chronos as opposed to eternity: "These glories [of eternity] were unimaginable - but the city was real" (p. 28). Eternity here is not continuous with the endless grind of chronos but is of a piece with the power of kairos to transcend that oppressive process. If the day of judgment determines eternity, the measure of judgment and the span of eternity are reduced to a single moment of kairos. The question of which measure shall prevail is not laid to rest here, for here for the first time we meet two principles of time vying to become John's reality: the aleatory moment of kairos and the necessary movement of chronos. Later, in 
the culminating section "The Threshing Floor," Baldwin will measure both time and eternity with kairos, the moment that explodes the framework of beginning, middle, and end.

Baldwin's inversion of values is the basis of John's self-recognition that will issue in a new freedom to pursue possibilities beyond the obvious, pious, binary oppositions of Gabriel's religion, the double imperative of jails or churches. In a paradox of perfect symmetry, the restful portion of John's day is blasphemous and the laborious portion pious, yet John's recreation in the city and his work in the church are alike an attempt to wrestle with God, as Jacob wrestled with the angel, to attain himself and his freedom. This wrestling takes literal form in the fight between John and the adolescent young man Elisha who plays the role of his mentor: "It was a deadlock; [Elisha] could not tighten his hold, John could not break it" (p. 48). To recall Genesis, the despised son John replaces the favored son Jacob; the haughty adolescent Elisha stands in for the angel of the Lord. If John wins the blessing, however, it is not a blessing of privilege conferred by the divine but of respect conferred by a fellow human. Hierarchy is not established but broken. Not even the hierarchy or binary opposition of straight and gay is left intact here. As Csapó observes, this encounter between John and Elisha appears to be marked by "homoerotic love": a love that is "confirmed" by the "holy kiss" between them. ${ }^{31}$ This holy kiss reverses John's sense that his masturbatory fantasy of "the boys, older, bigger, braver" amounts to $\sin$ (p. 11). If, as theologian Paul Tillich holds, sin is not immoral activity but separation and fate, the "sin" that John fantasizes is a kind of recognition of and reconciliation with his own desire and the freedom to live out this desire. ${ }^{32} \mathrm{Sin}$ in this sense is the opposite of the freedom enabled by kairos. As I shall show in an analysis of "The Threshing Floor," the redemption that overcomes the separation of $\sin$ is not reconciliation with God but reconciliation with self.

On the threshing floor, the final scene of John's revelation, he seems to experience an appearance of God and to be "set free" by the "Son" Jesus: John "was free-whom the Son sets free is free indeed-he had only to stand fast in his liberty" (p. 221). The "Son," here, is none other than John, who has set himself free in a mighty way. The incarnation, God becoming human, takes on a revolutionary new meaning in John's case. Liberation theologian James Cone acknowledges that God's "revelation is only for the oppressed of the land. He comes to those who have been enslaved and abused and declares his complete identification with their situation, disclosing to them the rightness of their emancipation on their own terms." ${ }^{33}$ This identification of God with the oppressed is what Cone means by the "blackness" of God, which resonates with Baldwin's own affirmation of Jesus' "darkness." ${ }^{34}$ In Baldwin's own appropriation of theology, in accordance with his remark to Nikki Giovanni that "God is our responsibility," the transcendent God becomes fully immanent in the life of John Grimes; the ultimate binary opposition between divinity and humanity collapses on the threshing floor. ${ }^{35}$

"The Threshing Floor" opens with an epigraph of the prophet Isaiah's vision of the Lord, in which the prophet takes up his vocation after having been convicted of $\sin .{ }^{36}$ Baldwin connects John both to an Old Testament prophet and to John of 
Patmos or John the Revelator, but with the difference of witnessing to the possible self-love, the return of self to self, not the return of Christ. ${ }^{37}$ In John's case, the prophetic ministry is inaugurated by a sight of the self and the transformation of a sense of sin into a sense of reconciliation with and recognition of the self. What counts as sin here? To follow Tillich, sin is separation-John's alienated suspension between Elisha and Gabriel, the desire for another man and the curse of his father (p. 197). There is the earlier sin of masturbation, the satiation of a queer desire, and there is the sin of seeing his father's nakedness, which, Baldwin makes clear, is equivalent to being black, to being an accursed son of Ham (p. 199). This apprehension of sin places John in the kairos of eternity: "in the moment, and out of time" (p. 200). Time becomes "indifferent" in the face of this kairotic moment. This moment is the fullness of time in which eternity invades the everyday.

Initially, God reveals himself as a powerful other to a passive and submissive John. This revelation of God as other is actually the first moment of John's selfrevelation. John must first encounter himself as other-in a state of sin, separated from himself-in order to begin the movement toward self-recognition or self-love. When John finds himself on the floor,

something moved in John's body that was not John. He was invaded, set at naught, possessed. This power had struck John, in the head or in the heart; and, in a moment, wholly, filling him with an anguish that he could never in his life have imagined, that he surely could not endure, that even now he could not believe, had opened him up; had cracked him open. (pp. 195-6)

This invasion, with its connotation of penetration by another, is the moment when John loses himself and begins the descent to the place from which he will deal with his father. From this point John's terrifying visions of his father, the injunction to set one's house in order, and the memory of his father's nakedness and the curse of Ham overwhelm him in a disordered whirl of chronology. To John, "Time was indifferent, like snow and ice; but the heart, crazed wanderer in the driving waste, carried the curse forever" (p. 200). It is this heart that carries the kairotic possibility of freedom, but John cannot yet realize this; the heart remains other to him. Strangely, this encounter with the other turns out to be the encounter with the self, symbolized in the otherness of darkness. The darkest part of John's experience in the moment of the threshing floor is a hatred of self, a humiliation at being himself and affirming his queer desire and his autonomy from Gabriel.

John finds himself abruptly "at the very bottom of darkness" (p. 196). Darkness, here, has a twofold meaning: it signifies both an abyss-an absence of meaning and a threat of nonbeing that is not just biological death but a kind of social death or non-recognition-at the same time that it signifies blackness: John's stigmatized racial subject position. The word darkness recurs incessantly and insistently throughout "The Threshing Floor," most strikingly in the phrase "the heart of darkness where he lay" (p. 198). Darkness, as the allusion to Joseph Conrad highlights, is a figure for John's horror at himself. Darkness is an abyss and a race, eternity and 
finitude: "His father's face was black-like a sad, eternal night" (p. 198). In a shift from past to present tense, Baldwin confirms the cramped infinity, the chronos, with which the darkness envelops John, such that "the utter darkness does not present any point of departure, contains no beginning, and no end" (p. 196). This equation of darkness with abyss and race, as well as John's misrecognition that blackness is a hideous thing, are seemingly confirmed a moment later in John's vision of "a woman, very old and black ... and he had never seen anyone so black" (p. 200). See Crawford for a reading of Go Tell It in relation to "racial self-hatred." John responds with desperate glee because, he thinks, "She's uglier than Mama! She's uglier than me!" (p. 201). ${ }^{38}$

The revelation on the threshing floor has begun with the paralyzing fear of being interpellated as black. John is prostrated on the floor, his body turning:

in his turning the center of the whole earth shifted, making of space a sheer void and a mockery of order, and balance, and time. Nothing remained: all was swallowed up in chaos. And: Is this it? John's terrified soul inquired-What is it?-to no purpose, receiving no answer. Only the ironic voice insisted yet once more that he rise from that filthy floor if he did not want to become like all the other niggers. (p. 196)

As an a priori condition of possibility for a world, for the experience of human life, time and space are disordered and "swallowed up in chaos." The chaos, or the primordial state before creation, becomes equivalent to the darkness, the abyss as well as the degraded, unrecognized condition of being called a "nigger."

Thus, John confronts his own darkness: the void of his desire-as represented by Elisha-and the curse of his blackness in the figure of Gabriel. John confronts sin and realizes that what he has called sin exhausts his own being. He must redescribe the sin, not as virtue, but as himself. He must end the misrecognition, the separation from self, that is called sin, and he must rather recognize the sin as himself: love or affirm himself as queer and black in order potentially to be free of the trap of chronos. Only then might he seize on the potential to become what he is, not to remain as he is misrecognized. John has returned to the inchoate, chaotic state prior to creation just so that he can reverse the maledictory effects of heritage and properly recognize himself. He must reverse the curse of Ham, not by being unlike all other accursed black people, but by accepting his darkness or blackness as a sign of affirmation and blessing rather than a sign of sin.

The dark chronos that John apprehends is a place of nonbeing or what John sees as "the grave," where "there was no speech or language, and there was no love; no one to say: You are beautiful, John; no one to forgive him, no matter what his sin" (pp. 202-3). John was struck earlier in the day by the fear that he is ugly, a fear he connects with his own gaze and the gaze of the white passersby-perhaps the latter gaze internalized as the former. For John, darkness is a place of sin, that is, a place where he finds himself loveless and ugly because of his sinful queerness, his accursed blackness. When the darkness does take on a kind of quasi-language, it is as the death of language, the death of connection between people. Indeed, it 
witnesses to the violence of lynching: "the darkness hummed with murder: the body in the water, the body in the fire, the body on the tree" (p. 203). This vision of white mob violence is a turning point, a kairotic moment, in the threshing floor experience. John sees the darkness no longer simply equated with blackness but with whiteness-the white supremacist "armies of darkness" responsible for this violence against African Americans (p. 203).

John is "searching something" in the darkness "that must be found" (p. 202). Baldwin does not name the thing that John is searching. Significantly, he does not say John is searching for something but that he is searching something, as if John is plumbing depths rather than looking around for something in particular; John plumbs the depths of his soul to find the capacity for love. But he begins to come out of this "terrible journey" into self-recognition when he hears a voice enjoining him to "go through. Go through" (p. 205). John is unable to lift himself, however, until first he sees the multitude, and then he sees the Lord, whereupon the darkness is filled with light: "John saw the Lord-for a moment only; and the darkness, for a moment only, was filled with a light he could not bear" (pp. 206-7). Just as the penetration of the other signals the beginning of the revelation, so the apprehension of the Other-God-seems to seal the culmination and ending of the revelation.

What is revealed here? On the one hand, the sight of the Lord seems to contrast with the darkness or blackness of which John has hitherto been ashamed. On the other hand, the revelation seems to free John from shame. Darkness and light are no longer maintained in opposition but converge in the revelation of God. This convergence simultaneously reveals God as immanent in the figure of the young man; there is a deep resonance between the two beings when the light is revealed to be fairly dark, and the young man is filled with light. It would be a stretch to call this revelation an identity, but this unitive moment becomes a mystical source of self-love.

John returns to ordinary consciousness, "open[ing] his eyes on the morning, and found them [the congregation], in the light of the morning, rejoicing for him" (p. 207). He returns from his kairotic moment of self-recognition in which eternity penetrated the night and finds chronos transformed. Chronos is racked with the same oppressions as before, but John is free for the first time, just because he can counter the misrecognition of others with his own robust sense of self-recognition, having claimed his darkness as his own and emerged onto the light of the morning:

He would weep again, his heart insisted, for now his weeping had begun; he would rage again, said the shifting air, for the lions of rage had been unloosed; he would be in darkness again, in fire again, now that he had seen the fire and the darkness. He was free-whom the Son sets free is free indeed - he had only to stand fast in his liberty. (pp. 220-1)

In the ultimate moment of the book, John will act on his freedom, his divine agency, turning from his father to his mother and declaring, with a sovereign word, that he is returning home: "I'm coming. I'm on my way" (p. 226). He demonstrates a 
free choice between two options. He turns away from his father and his father's determining power.

At the end of Go Tell It on the Mountain John Grimes is hardly "lighting out for the territory," the dream of unfettered freedom that is, as Toni Morrison argues, the obsession of the American literary history of white manhood. ${ }^{39}$ John is remaining, for the moment at least, at Gabriel's house. Baldwin acknowledges the power of chronos, but the kairos that broke onto the threshing floor the night before has overwhelmed chronos: the limitation of chronos is exploded with the eternal moment of kairos. The book of Revelation ends with Christ's promise to "come quickly" and the writer's answer, "even so, come Lord Jesus." ${ }^{0}$ The difference Baldwin introduces between the biblical reference and the final moment of his novel is crucial. In the New Testament, the agent to come is Christ. But in Go Tell It on the Mountain, the agent who arrives is John. Telling the story of John's passage toward self-love-the narrative arc of Go Tell It on the Mountain-functioned as a kind of workingthrough of "what hurt most" for Baldwin: it was most broadly the paternal past, chronos, that hurt most. In a refiguring of chronos into kairos, Baldwin implies his own possibility of recognition and a kind of liberation from the necessity of history. The kairos of Go Tell It on the Mountain opens a utopian space from which Baldwin can witness history and witness against it.

\section{Notes}

1 Quoted in Leslie Bennetts, "James Baldwin Reflects on 'Go Tell It' PBS Film," New York Times, 10 January 1985, www.nytimes.com/1985/01/10/books/james-baldwin-reflectson-go-tell-it-pbs-film.html (accessed 12 June 2018).

2 David Leeming, James Baldwin: A Biography (New York, Alfred A. Knopf, 1994), p. 86.

3 Fredric Jameson, The Political Unconscious: Narrative as a Socially Symbolic Act (Ithaca, N.Y., Cornell University Press, 1981), p. 103.

4 Mikko Tuhkanen, "Watching Time: James Baldwin and Malcolm X," James Baldwin Review, 2 (2016), p. 100.

5 Ibid., p. 108.

6 Ibid., p. 114.

7 As Baldwin holds, the capacity to love- "to be larger, freer, and more loving"-is potentially enabled by religious language. According to Baldwin's essay "Down at the Cross," the expansion of our ability to love-the core of our redemptive agency-is the core of the concept of God, for "If the concept of God has any validity or any use, it can only be to make us larger, freer, and more loving." See James Baldwin, "Down at the Cross" (1963), in Collected Essays, ed. Toni Morrison (New York, Library of America, 1998), p. 314 .

8 Mark 1:14-15 in The King James Open Bible (Nashville, TN, Thomas Nelson, 1985), p. 978. This example of the use of kairos is taken from George Abbott-Smith, A Manual Greek Lexicon of the New Testament (Edinburgh, T. \& T. Clark, 1922), p. 226.

9 H.-C. Hahn, “Kairos," in Colin Brown (ed.), The New International Dictionary of New Testament Theology (Grand Rapids, MI, Zondervan, 1975), p. 834.

10 Ibid., p. 840.

11 Ibid., p. 837. 
12 James Baldwin, Go Tell It on the Mountain (1953) (New York, Vintage, 2013), p. 75. All subsequent quotations are taken from this edition. Page numbers are given in parentheses in the text.

13 James Baldwin, "Many Thousands Gone" (1955), in Morrison (ed.), Collected Essays, p. 23.

14 James Baldwin and Nikki Giovanni, A Dialogue (Philadelphia, PA, J. B. Lippincott, 1973), p. 37.

15 Barbara K. Olson, “'Come-to-Jesus Stuff' in James Baldwin's 'Go Tell It on the Mountain’ and 'The Amen Corner," African American Review, 31:2 (1997), p. 296.

16 Michael F. Lynch, "A Glimpse of the Hidden God: Dialectical Vision in Baldwin's Go Tell It on the Mountain," in Trudier Harris (ed.), New Essays on Go Tell It on the Mountain (New York, Cambridge University Press, 1996), p. 54.

17 Ibid., p. 30.

18 George Shulman, American Prophecy: Race and Redemption in American Political Culture (Minneapolis, MN, University of Minnesota Press, 2008), p. 132.

19 James Baldwin and Margaret Mead, A Rap on Race (New York, Dell, 1992), pp. 85-6.

20 Ibid., p. 86.

21 This sense of recognition as love should be distinguished from Aristotelian anagnorisis, which is tied to identity. As Aristotle defines the term, anagnorisis or recognition is "a shift from ignorance to awareness, pointing in the direction either of close blood ties or of hostility, of people who have previously been in a clearly marked state of happiness or unhappiness." See Aristotle, Poetics, trans. Gerald F. Else (Ann Arbor, MI, University of Michigan Press, 1970), p. 36.

22 Axel Honneth, The Struggle for Recognition: The Moral Grammar of Social Conflicts, trans. Joel Anderson (Cambridge, MA, MIT Press, 1995), especially chapter 5.

23 Greg Miller, "James Baldwin," in Jay Parini (ed.), The Oxford Encyclopedia of American Literature, Vol. 4 (Oxford, Oxford University Press, 2004), p. 117.

24 Shirley S. Allen, "Religious Symbolism and Psychic Reality in Baldwin's Go Tell It on the Mountain," in Fred L. Standley and Nancy V. Burt (eds.), Critical Essays on James Baldwin (Boston, G. K. Hall, 1988), p. 168.

25 See the analysis of allusions to Revelation in Joseph A. Brown, "I, John, Saw the Holy Number: Apocalyptic Visions in 'Go Tell It on the Mountain' and 'Native Son," Religion and Literature, 27:1 (1995), pp. 53-4. In his biography James Baldwin, David Leeming points out that the figure of the "threshing floor" is a metaphor from the message of John the Baptist. See p. 86.

26 Csaba Csapó, "Race, Religion and Sexuality in Go Tell It on the Mountain," in Carol E. Henderson (ed.), James Baldwin's Go Tell It on the Mountain: Historical and Critical Essays (New York, Peter Lang, 2006), p. 63.

27 John R. May sees the novel as beginning not with Creation but with the seventh day as "the last day of the week and suggestive of the last age of the world," to be followed by "the morning of the eighth - the first day of the new creation, the day of ultimate salvation." See John R. May, "Images of the Apocalypse in the Black Novel," Renascence, 23:1 (1970), p. 37.

28 According to Margo Natalie Crawford, it is in John's desire for Elisha that Baldwin "locates a homoerotic spirituality that emerges as a liberation theology" Margo Natalie Crawford, "The Reclamation of the Homoerotic as Spiritual in Go Tell It on the Mountain," in Henderson (ed.), James Baldwin's Go Tell It on the Mountain, p. 76. For Crawford, Baldwin sanctifies the homoerotic kiss between John and Elisha as holy. See p. 79. 
29 Csapó, “Race," p. 57. Michael Cobb also proposes a queer religious reading of the novel, treating religious language as a normative rhetoric through which queer people like John Grimes can articulate their identity in such a way that they attain a sense of "belonging" in the public sphere. Such religious language is ambiguous though, Cobb argues, because, on the one hand, it is violent, conservative, and homophobic, and on the other hand, it offers a sense of belonging. This belonging, then, is premised on misrecognition of queer people. Michael Cobb, God Hates Fags: The Rhetorics of Religious Violence (New York, New York University Press, 2006), ch. 2.

30 John's question about ugliness is inspired by looking in a mirror, a scene Crawford classifies as a kind of Lacanian "recognition that is misrecognition." See Crawford, "Reclamation," p. 77.

31 Csapó, "Race," pp. 65, 71, 72.

32 Paul Tillich, "You Are Accepted," in The Shaking of the Foundations (New York, Scribner's, 1948), pp. 154-5.

33 James H. Cone, A Black Theology of Liberation (Philadelphia, PA, J. B. Lippincott, 1970), p. 91.

34 Ibid., p. 121.

35 Baldwin and Giovanni, A Dialogue, p. 38.

36 Isaiah 6, in King James Open Bible, pp. 662-3.

37 The Book of Revelation is alluded to, e.g., on pp. 204, 207, and in Go Tell It's final words, in which John's "coming" rhymes with the hope of Christ's return.

38 See Crawford for a reading of Go Tell It in relation to "racial self-hatred."

39 Toni Morrison, Playing in the Dark: Whiteness and the Literary Imagination (Cambridge, MA, Harvard University Press, 1992), pp. 37-9.

40 Revelation 22:20, in The King James Open Bible, p. 1283.

\section{Works Cited}

Abbott-Smith, George, A Manual Greek Lexicon of the New Testament (Edinburgh, T. \& T. Clark, 1922).

Allen, Shirley S., "Religious Symbolism and Psychic Reality in Baldwin's Go Tell It on the Mountain," in Fred L. Standley and Nancy V. Burt (eds.), Critical Essays on James Baldwin (Boston, G. K. Hall, 1988), pp. 166-88.

Aristotle, Poetics, trans. Gerald F. Else (Ann Arbor, MI, University of Michigan Press, 1970).

Baldwin, James, "Down at the Cross" (1963), in Collected Essays, ed. Toni Morrison (New York, Library of America, 1998), pp. 296-347.

Go Tell It on the Mountain (1953) (New York, Vintage, 2013).

"Many Thousands Gone" (1955), in Collected Essays, ed. Toni Morrison (New York, Library of America, 1998), pp. 19-34.

Baldwin, James, and Nikki Giovanni, A Dialogue (Philadelphia, PA, J. B. Lippincott, 1973).

Baldwin, James, and Margaret Mead, A Rap on Race (New York, Dell, 1992).

Bennetts, Leslie, "James Baldwin Reflects on 'Go Tell It' PBS Film," New York Times, 10 January 1985, www.nytimes.com/1985/01/10/books/james-baldwin-reflects-on-gotell-it-pbs-film.html (accessed 12 June 2018).

Brown, Joseph A., "I, John, Saw the Holy Number: Apocalyptic Visions in 'Go Tell It on the Mountain' and 'Native Son,”' Religion and Literature, 27:1 (1995), pp. 53-74. 
Cobb, Michael, God Hates Fags: The Rhetorics of Religious Violence (New York, New York University Press, 2006).

Cone, James H., A Black Theology of Liberation (Philadelphia, PA, J. B. Lippincott, 1970).

Crawford, Margo Natalie, "The Reclamation of the Homoerotic as Spiritual in Go Tell It on the Mountain," in Carol E. Henderson (ed.), James Baldwin's Go Tell It on the Mountain: Historical and Critical Essays (New York, Peter Lang, 2006), pp. 75-86.

Csapó, Csaba, "Race, Religion and Sexuality in Go Tell It on the Mountain," in Carol E. Henderson (ed.), James Baldwin's Go Tell It on the Mountain: Historical and Critical Essays (New York, Peter Lang, 2006), pp. 57-74.

Hahn, H.-C., "Chronos," in Colin Brown (ed.), The New International Dictionary of New Testament Theology (Grand Rapids, MI, Zondervan, 1975), pp. 839-45.

"Kairos," in Colin Brown (ed.), The New International Dictionary of New Testament Theology (Grand Rapids, MI, Zondervan, 1975), pp. 833-9.

Honneth, Axel, The Struggle for Recognition: The Moral Grammar of Social Conflicts, trans. Joel Anderson (Cambridge, MA, MIT Press, 1995).

Jameson, Fredric, The Political Unconscious: Narrative as a Socially Symbolic Act (Ithaca, N.Y., Cornell University Press, 1981).

The King James Open Bible (Nashville, TN, Thomas Nelson, 1985).

Leeming, David, James Baldwin: A Biography (New York, Alfred A. Knopf, 1994).

Lynch, Michael F., "A Glimpse of the Hidden God: Dialectical Vision in Baldwin's Go Tell It on the Mountain," in Trudier Harris (ed.), New Essays on Go Tell It on the Mountain (New York, Cambridge University Press, 1996), pp. 29-57.

May, John R., "Images of Apocalypse in the Black Novel," Renascence, 23:1 (1970), pp. 31-45.

Miller, Greg, "James Baldwin," in Jay Parini (ed.), The Oxford Encyclopedia of American Literature, Vol. 4 (Oxford, Oxford University Press, 2004), pp. 117-24.

Morrison, Toni, Playing in the Dark: Whiteness and the Literary Imagination (Cambridge, MA, Harvard University Press, 1992).

Olson, Barbara K., "'Come-to-Jesus Stuff' in James Baldwin's 'Go Tell It on the Mountain' and 'The Amen Corner," African American Review, 31:2 (1997), pp. 295-301.

Shulman, George, American Prophecy: Race and Redemption in American Political Culture (Minneapolis, MN, University of Minnesota Press, 2008).

Tillich, Paul, "You Are Accepted," in The Shaking of the Foundations (New York, Scribner's, 1948), pp. 153-63.

Tuhkanen, Mikko, "Watching Time: James Baldwin and Malcolm X," James Baldwin Review, 2 (2016), pp. 97-125.

\section{Contributor's Biography}

Robert Z. Birdwell is Visiting Assistant Professor of English at Tulane University. His book The Radical Novel and the Classless Society: Utopian and Proletarian Novels in U.S. Fiction from Bellamy to Ellison is forthcoming from Lexington Books/Rowman and Littlefield. 